\title{
Crustal Evolution of a Paleozoic Intra-oceanic Island-Arc-Back-Arc Basin System Constrained by the Geochemistry and Geochronology of the Yakuno Ophiolite, Southwest Japan
}

\author{
Yoshimitsu Suda, ${ }^{1,2}$ Yasutaka Hayasaka, ${ }^{3}$ and Kosuke Kimura ${ }^{3}$ \\ ${ }^{1}$ Center for Obsidian and Lithic Studies, Meiji University, Nagano 386-0601, Japan \\ ${ }^{2}$ Department of Geology, Faculty of Education, Nagasaki University, Nagasaki 825-8521, Japan \\ ${ }^{3}$ Department of Earth and Planetary Systems Science, Hiroshima University, Higashihiroshima 739-8526, Japan \\ Correspondence should be addressed to Yoshimitsu Suda; geosuda@gmail.com
}

Received 9 December 2013; Revised 6 March 2014; Accepted 16 April 2014; Published 28 May 2014

Academic Editor: Ryszard Kryza

Copyright (C) 2014 Yoshimitsu Suda et al. This is an open access article distributed under the Creative Commons Attribution License, which permits unrestricted use, distribution, and reproduction in any medium, provided the original work is properly cited.

\begin{abstract}
The Yakuno ophiolite in southwest Japan is considered to have been obducted by the collision between an intrao-ceanic islandarc-back-arc basin (intra-OIA-BAB) system and the East Asian continent during the late Paleozoic. New SIMS (SHRIMP) zircon $\mathrm{U}-\mathrm{Pb}$ determinations for amphibolite and metagabbro of $\mathrm{BAB}$ origin within the Yakuno ophiolite yield ages of $293.4 \pm 9.5 \mathrm{Ma}$ and $288 \pm 13 \mathrm{Ma}$, respectively. These ages are slightly older (however, overlapping within analytical errors) than the magmatic age of arc granitoids (ca. 285-282 Ma) that intruded into the mafic rocks of BAB origin. Results from geochronological and geochemical data of the Yakuno ophiolite give rise to the following tentative geotectonic model for the Paleozoic intra-OIA-BAB system: the initial stage of BAB rifting (ca. 293-288 Ma) formed the BAB crust with island-arc basalt (IAB) signatures, which was brought to the OIA setting, and generated the arc granitoids (ca. 285-282 Ma) by anatexis of the BAB crust. A later stage of BAB rifting (<ca. $285 \mathrm{Ma}$ ) formed the BAB crust with IAB to MORB signatures, on which the Permian sediments were conformably deposited. These components collided with the eastern margin of the East Asian continent during the early Mesozoic.
\end{abstract}

\section{Introduction}

Ophiolites are the rock assemblages of peridotite, gabbro, basalt, and associated pelagic sediment found at the orogenic belt of a convergent plate boundary. They are most commonly interpreted as the remnants of crustal components and the upper mantle beneath an ocean basin [1-3]. Therefore, ophiolites provide direct information about the deeper part of the crustal section without the need for deep drilling and are considered to be significant research target on the reconstruction of paleotectonic evolution of orogenic belts [1-4].

The Yakuno ophiolite in southwest Japan originated from the crustal sections of a Paleozoic intra-oceanic island-arcback-arc basin (intra-OIA-BAB) system and formed through collision and accretion with the eastern margin of the East
Asian continent during the early Mesozoic [5, 6]. The Yakuno ophiolite in the Asago area is composed of metagabbro and amphibolite of BAB origin (Figure 1) [7]. These mafic rocks are intruded by the granitoid of arc affinities. This field evidence suggests that the mafic rocks in this area originally formed as a BAB crust, which was subsequently brought to an OIA setting. In this regard, the Yakuno ophiolite in this area records various lines of evidence to help understand the tectonic evolution of an intra-OIA-BAB system $[7,8]$.

The zircon U-Pb TIMS ages of $282 \pm 2 \mathrm{Ma}$ and $285 \pm 2 \mathrm{Ma}$ were determined from the arc granitoid (i.e., tonalite and granodiorite) in the Asago area by Herzig et al. [9]. The ages were considered to be the period of the magmatic activity under the island-arc or intra-OIA setting. On the other hand, the magmatic age of the Yakuno ophiolite originated from the $\mathrm{BAB}$ crust has not yet been determined. The present study 


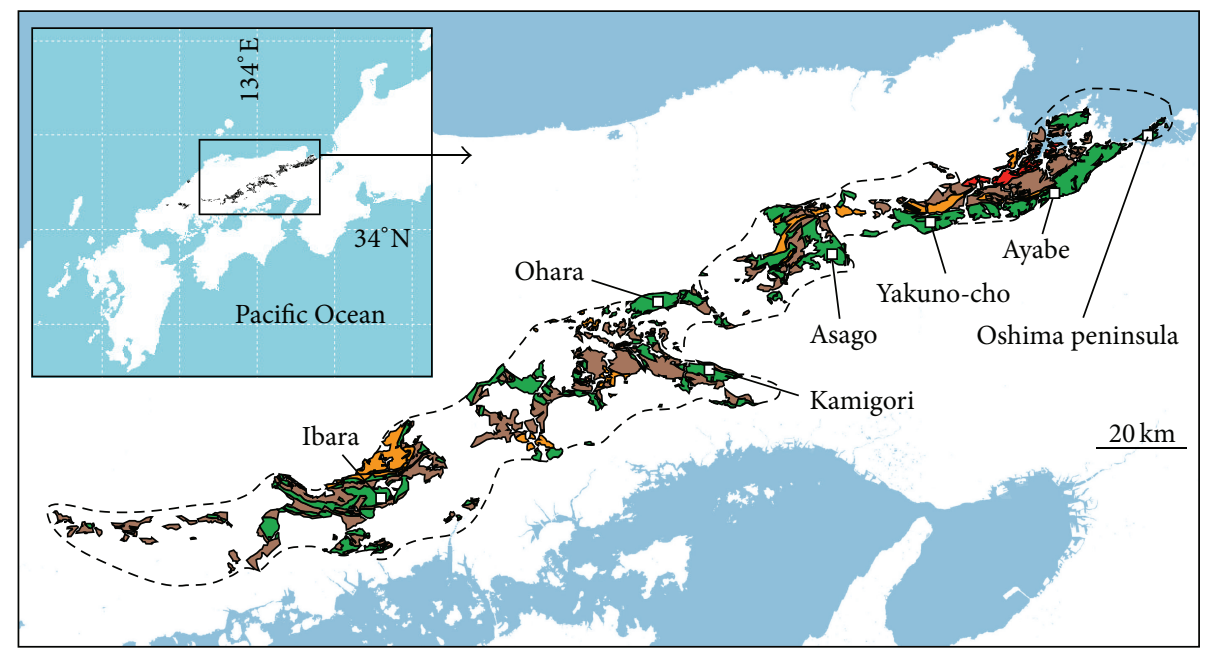

Maizuru Terrane
$\square$ Triassic sediments
$\square$ Northern Zone

Inner Zone (Maizuru Group)

Southern Zone (Yakuno ophiolite)

FIgURE 1: Distribution of the Maizuru Terrane in southwest Japan.

reports the SIMS (SHRIMP: sensitive high resolution ion microprobe) zircon $\mathrm{U}-\mathrm{Pb}$ ages from the mafic rocks of $\mathrm{BAB}$ origin in the Asago area. On the basis of the compilation for the geological and geochronological data about the Yakuno ophiolite and associated rocks, we tentatively propose a geotectonic model and time scale for the Yakuno ophiolite in the context of the tectonic evolution of an intra-OIA-BAB system.

\section{Yakuno Ophiolite in Maizuru Terrane}

2.1. Geology. The Yakuno ophiolite is found in the upper Paleozoic to lower Mesozoic Maizuru Terrane in southwest Japan $[5,6]$. The Maizuru Terrane is characterized by a distinct zonal structure with an extension of northeastern to southwestern direction and divided, based on lithology, into the Northern Zone, the Inner Zone, and the Southern Zone. The Maizuru Terrane comprises the following four major lithological units (Figure 1): (1) granitoid with a minor amount of pelitic gneiss and amphibolite in the Northern Zone, (2) Permian sediments of the Maizuru Group in the Inner Zone, (3) metamorphic peridotite, metagabbro, and amphibolite with minor amount of granitoid in the Southern Zone, and (4) Triassic sediments, which uncomfortably cover the rocks in Inner and Southern Zones.

The Yakuno ophiolite indicates the metamorphosed ultramafic to mafic rocks of peridotite, metagabbro, and amphibolite found in the Southern Zone. Previous works have reported that these rocks were originated from various kinds of upper mantle to crustal sections of ocean basin (OB) (i.e., MORB origin), intra-oceanic island-arc (intraOIA), and back-arc basin (BAB) $[5,6]$.

2.2. Yakuno Ophiolite in Oshima Peninsula, Ayabe, and Yakuno-cho Areas. The Yakuno ophiolite in the Oshima peninsula and Ayabe areas (Figure 1) consists of ultramafic rock of upper mantle origin and mafic rocks of OIA and BAB origins. Ishiwatari [10] reported that harzburgite is observed predominantly in the Oshima peninsula area and originated from the upper mantle after the extraction of roughly $35 \%$ volume of basaltic magma. Ishiwatari [10] further indicated that the metabasalt and metagabbro in the Oshima peninsula and Ayabe areas possess geochemical affinities of MORB and are derived from a T-type MORB source.

Ichiyama and Ishiwatari [11] suggested that the Yakuno ophiolite in the Yakuno-cho area (Figure 1) originated from a $\mathrm{BAB}$ crust, consisting of metabasalt and metagabbro of BAB affinities and a minor amount of troctolite.

2.3. Yakuno Ophiolite and Associated Rocks in Asago Area. Hayasaka et al. [6] indicated that the Yakuno ophiolite in the Asago area (Figure 1) consists of the crustal components of three different tectonic settings: OB, intra-OIA, and BAB. Each of the components of different tectonic settings is bounded by a low-angle fault (Figure 2(a)).

Suda [8] and Suda and Hayasaka [7] suggested that the amphibolite and metagabbro in the Asago area possess geochemical affinities of $\mathrm{BAB}$ basalt (BABB), which are derived from a tholeiitic $\mathrm{BABB}$ source. These mafic rocks of $\mathrm{BABB}$ affinities are intruded by tonalite, quartz-diorite, and granodiorite of arc affinities. The presence of migmatites in the lower crustal level implies that the granitoid was formed by the lower crustal anatexis of the mafic rocks derived from $B A B B$ source. When combined, these findings indicate that the amphibolite and metagabbro in this area originally formed as a BAB crust, which was subsequently brought to an intra-OIA setting in which the granitoids of arc affinities were generated. Geological map and geologic columnar section indicating the relation between these components are shown in Figures 2(a) and 2(b), respectively. Localities of the samples 


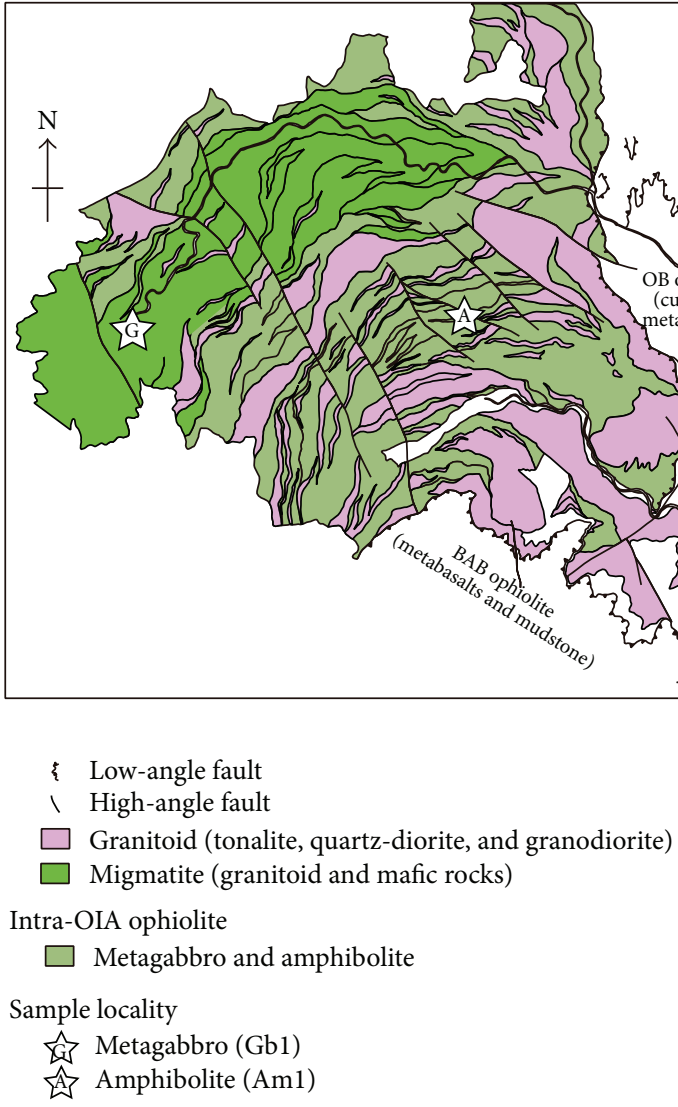

(a)

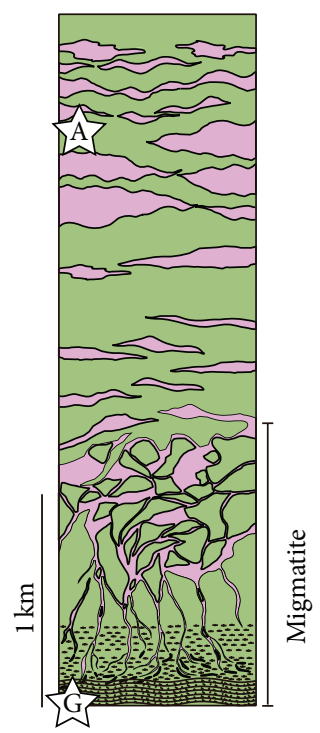

(b)

Figure 2: Geological map (a) and schematic columnar section (b) of the Yakuno ophiolite and associated rocks in the Asago area [8].

for the SHRIMP zircon dating performed in the present study are also indicated in these figures.

Hayasaka [12] suggested that the cumulate metagabbro (pyroxenite, anorthosite, and eucrite) in the Asago area is rather similar in petrography and geochemistry to those in the Oshima peninsula and Ayabe areas (Figure 1), thus suggesting that this metagabbro originated from a lower crustal section of oceanic crust and was derived from the Ttype MORB source (i.e., OB ophiolite) (Figure 2(a)).

Hayasaka et al. [6] indicated that metadolerites, metabasalts, and massive mudstone in the Asago area were derived from the upper crust in a $\mathrm{BAB}$ setting (i.e., $\mathrm{BAB}$ ophiolite) (Figure 2(a)). The intercalation of mudstone with the metabasalt implies that these rocks formed under an environment of simultaneous sedimentation and eruption of basalt, further supporting the interpretation of a BAB setting.

2.4. Yakuno Ophiolite and Associated Rocks in Ohara and Kamigori Areas. Ishiwatari et al. [5] and Ishiwatari [13] indicate that the Yakuno ophiolite in the Ohara and Kamigori areas, consisting of metagabbro and amphibolite of IAB affinities and a minor amount of shoshonitic metagabbro (Figure 1), originated from the lower crust in an OIA setting.

2.5. Yakuno Ophiolite and Associated Rocks in Ibara Area. The Yakuno ophiolite in the Ibara area was derived from the upper crust in a BAB setting (Figure 1) [14]. The Yakuno ophiolite in this area consists of metagabbro, metabasalt, and massive mudstone. The metabasalt is intercalated with the mudstone and possesses geochemical affinities of $\mathrm{BABB}$, which supports the interpretation of a $\mathrm{BAB}$ setting.

2.6. Permian Maizuru Group. The Maizuru Group in the Inner Zone of the Maizuru Terrane is found alongside the exposure of the Yakuno ophiolite and consists of alternating metabasalt and mudstone in the lower strata, a massive mudstone in the middle strata, interbedded sandstone and mudstone in the upper strata, and sandstone and conglomerate in the uppermost strata [15]. Radiolarians of early to middle Permian age (Pseudoalbaillella cf. fusiformis) are reported from the lower strata [16], and radiolarians of middle to late Permian age are reported from the middle to upper strata [17]. This stratigraphic sequence is characterized by an increase of terrigenous deposits with increasing structural level, and a marginal sea basin of relatively shallow depth is assumed as the sedimentary environment [15].

Ishiwatari [13] considered that the tectonic relationship between the Maizuru Group and the Yakuno ophiolite of $\mathrm{BAB}$ setting was originally conformable. The lower strata of the Maizuru Group are equivalent to the upper part of the Yakuno ophiolite and are characterized by the intercalation of mudstone with metabasalt. 
2.7. Triassic Sediments. The Triassic sediments in the Maizuru Terrane consist of conglomerate, sandstone, and mudstone, which unconformably overlie the Yakuno ophiolite and the Maizuru Group (Figure 1). Early to late Triassic ammonoids and bivalves are reported from the Triassic sediments $[18,19]$, which are assumed to have been deposited in beach, shore, and brackish water sedimentary environments.

2.8. Hinterland Models for the Permo-Triassic Sediments. Geochronological data from the detrital zircon and paleobiogeographical results from the Triassic sediments suggest that the East Asian continent was the hinterland for the PermoTriassic sediments in the Maizuru Terrane, namely, the South China Craton [20], the North China Craton [21], and the Khanka Massif or the Northern Zone of the Maizuru Terrane [22]. The Yakuno ophiolite and Maizuru Group collided with the eastern margin of the East Asian continent during the beginning of the Mesozoic.

\section{SHRIMP U-Pb Zircon Dating}

3.1. Samples. We performed SHRIMP zircon U-Pb age dating at Hiroshima University, Japan, to clarify the magmatic or protolith age of the Yakuno ophiolite of BAB setting. The zircons used for the dating were separated from samples of metagabbro (Gb1) and amphibolite (Aml) in the Asago area (Figure 1). The outcrop from which sample Gb1 was taken is located at latitude $35.232209^{\circ} \mathrm{N}$ and longitude $134.709694^{\circ} \mathrm{E}$ and represents the structurally lowermost part of the ophiolite (Figure 2(b)). The outcrop for sample Am1 is located at latitude $35.234321^{\circ} \mathrm{N}$ and longitude $134.748472^{\circ} \mathrm{E}$ and represents the structurally upper part (Figure 2(b)).

Suda [8] indicates that both the metagabbro and amphibolite exhibit various degrees of deformation and metamorphic textures, such as gneissosity with a preferred orientation of minerals. Foliation and lineation are strongly developed in the amphibolite suite in particular. Gneissose metagabbro is gradually replaced by amphibolite in the upper part. In the lowermost part, the metagabbro contains hornblende + clinopyroxene + orthopyroxene + plagioclase \pm quartz mineral assemblage indicating granulite-facies metamorphism. All the orthopyroxene crystals are replaced by bastite, and plagioclase is moderately saussuritized because of hydrothermal alteration. Pyroxene declines in abundance upwards, and the mineral paragenesis changes to hornblende + plagioclase \pm clinopyroxene, indicating amphibolite-facies metamorphism. Apatite commonly occurs as an accessory mineral along with minor amounts of $\mathrm{Fe}-\mathrm{Ti}$ oxides.

3.2. Method. Using a jaw crusher and stamp mill, chips of rock samples were crushed into powdered particles of $<250 \mu \mathrm{m}$ in size. Heavy minerals were concentrated from the powdered sample by hydraulic elutriation and magnetic means. Zircon grains were handpicked, mounted in epoxy resin, and polished using diamond paste until they were reduced to approximately half their original thickness. Before isotopic analysis, in addition to microscopic observation,
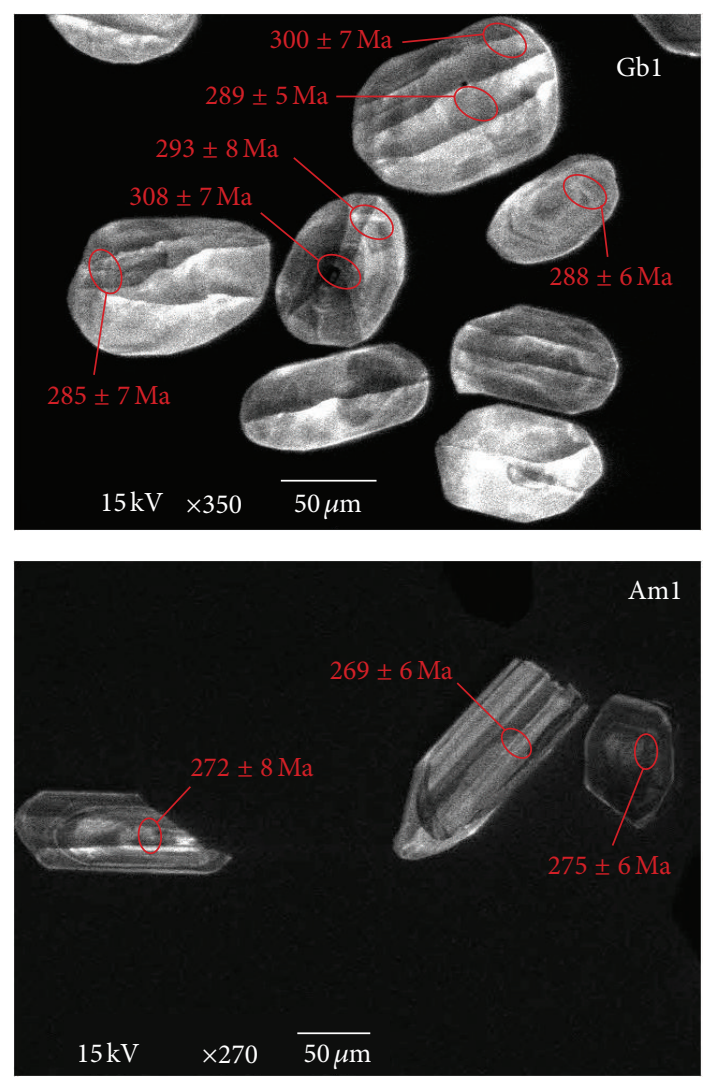

FIgURE 3: Cathodoluminescence image of representative zircons used for SHRIMP dating of the metagabbro $(\mathrm{Gbl})$ and the amphibolite (Aml).

back-scattered electron (BSE) images and cathodoluminescence (CL) images were taken with an EPMA (electron probe micro-analyzer) to check for metamict regions, inclusions, and compositional zoning patterns. All the measured points for SHRIMP analysis were selected using the BSE and CL images. The isotopic analysis of zircon was performed using a SHRIMP-II machine at Hiroshima University. The procedures for $\mathrm{U}$ and $\mathrm{Pb}$ isotopic analysis and dating were the same as those used by Fujii et al. [22]. Isoplot/Ex 3.0 [23] was used for age calculations (Figures $4(\mathrm{a})$ and $4(\mathrm{~b})$ ).

3.3. Results and Interpretation. The zircon grains in the Gb1 (metagabbro) generally have round shape, in which oscillatory igneous zoning texture is blurred (Figure 3). Many lines visible in the CL images of Gb1 zircon show the cracks formed during sample preparation (Figure 3). On the Tera and Wasserburg [24] diagram, the analyzed 11 spots plot on the concordia (Table 1), from which a weighted mean concordant ${ }^{206} \mathrm{~Pb}^{*} /{ }^{238} \mathrm{U}$ age of $293.4 \pm 9.5 \mathrm{Ma}$ (all errors give $2 \sigma$ ) is estimated (Figure 4(a)). The probability plot for these spot ${ }^{206} \mathrm{~Pb}^{*} /{ }^{238} \mathrm{U}$ ages shows a unimodal distribution ranging from $281 \mathrm{Ma}$ to $308 \mathrm{Ma}$ (Figure $4(\mathrm{~b})$ ). These spot ages show no correlation with $\mathrm{Th} / \mathrm{U}$ ratios (Table 1 ).

The zircon grains in the Aml (amphibolite) have prismatic euhedral shape and texture but the crystals are often 


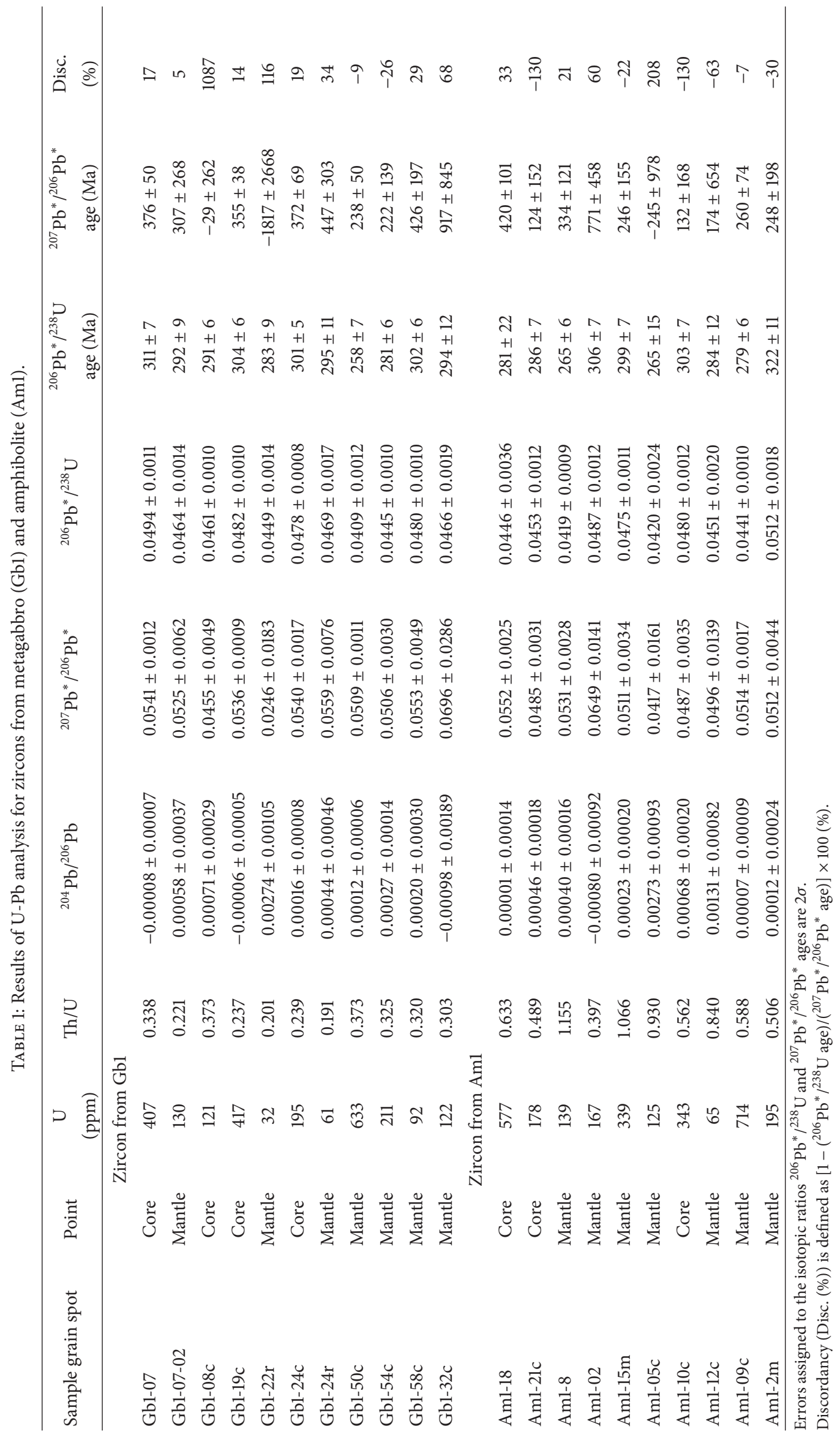



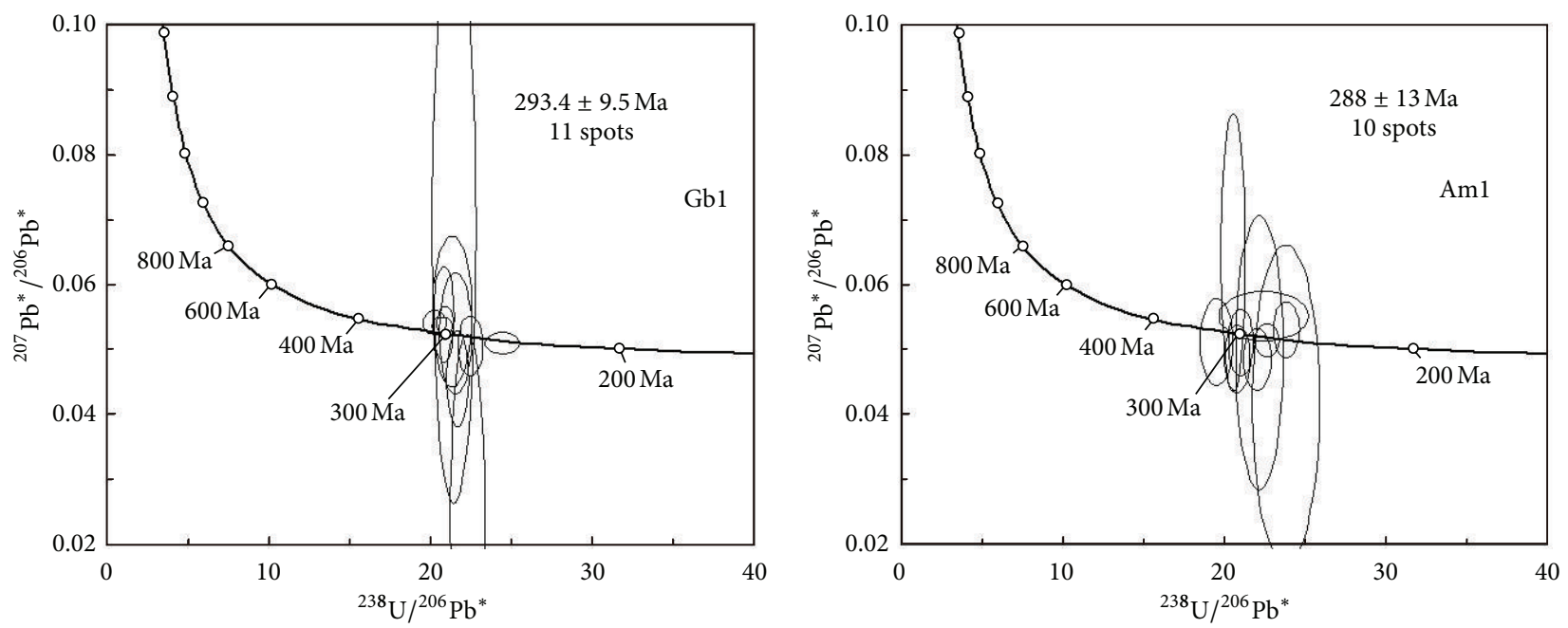

(a)
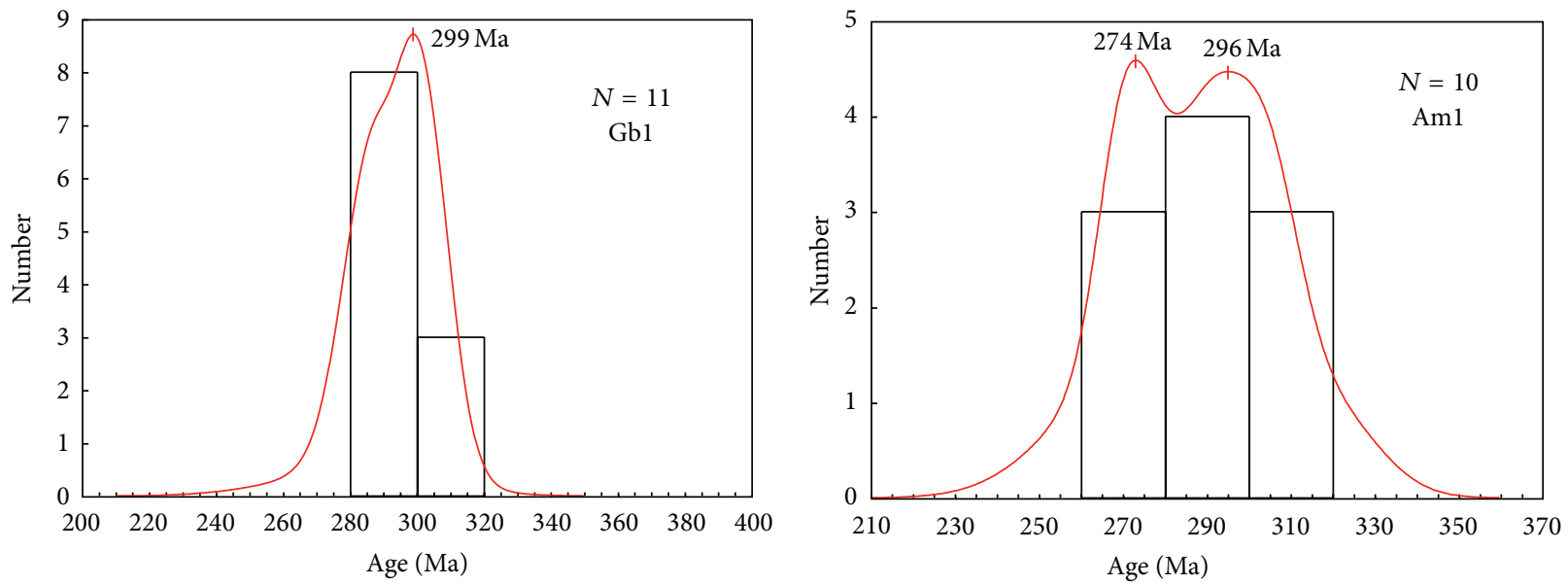

(b)

Figure 4: (a) Tera and Wasserburg [24] U-Pb zircon diagrams for metagabbro (Gb1) and amphibolite (Am1). Error ellipses indicate 2 $\sigma$. (b) Probability plot and histogram for the spot ${ }^{206} \mathrm{~Pb}^{*} /{ }^{238} \mathrm{U}$ ages and peak ages.

broken, in which typical oscillatory igneous zoning texture is observed (Figure 3). The analyzed 10 spots lying on the concordia (Table 1) give a weighted mean concordant ${ }^{206} \mathrm{~Pb}^{*} / 238 \mathrm{U}$ age of $288 \pm 13 \mathrm{Ma}$ (Figure 4(a)). The probability plot for these spot ${ }^{206} \mathrm{~Pb}^{*} /{ }^{238} \mathrm{U}$ ages roughly shows a unimodal distribution ranging from $264 \mathrm{Ma}$ to $319 \mathrm{Ma}$ (Figure $4(\mathrm{~b})$ ). There is no correlation with $\mathrm{Th} / \mathrm{U}$ ratios (Table 1 ).

The $T h / U$ ratios in the Gb1 zircon are relatively lower than those in the Aml zircon (Table 1). This may be related to Th loss due to the granulite-facies metamorphism. In this case, the calculated ${ }^{206} \mathrm{~Pb}^{*} / 238 \mathrm{U}$ age would become slightly younger. However, the Th/U ratio in the Gbl zircon is $>0.2$. This result strongly indicates that the Gbl zircon has not crystallized during the granulite-facies metamorphism but has crystallized from magma (i.e., igneous origin). The Th/U ratio in metamorphic zircon is generally $<0.07$ (e.g., Rubatto [25]). Namely, the zoning texture in Gbl zircon represents the blurred primary zoning. Furthermore, the results of ${ }^{206} \mathrm{~Pb}^{*}{ }^{238} \mathrm{U}$ ages from the $\mathrm{Gbl}$ and $\mathrm{Aml}$ are overlapping within $2 \sigma$ error. From these results, we conclude that the ${ }^{206} \mathrm{~Pb}^{*} /{ }^{238} \mathrm{U}$ ages obtained from the Gbl and Aml zircons represent the age of magmatic crystallization of these mafic rocks.

\section{Discussion}

4.1. Overview of Intra-OIA-BAB System. An intra-OIA-BAB system is generally formed by the subduction of an oceanic plate at an oceanic-oceanic convergent plate boundary [26]. Previous studies of various intercontinental suture zones have proposed multiple lines of evidence for continental growth by accretion of intra-OIA-BAB systems [27, 28]. In the Cenozoic intra-OIA-BAB system of the Izu-Bonin-Mariana (IBM) arc, the middle crust of the intra-OIA was emplaced within the Honshu arc in the Tanzawa Mountains of Japan due to the subduction of the Philippine Sea Plate beneath the Eurasian Plate $[29,30]$. Thus, the tectonic history of an intra-OIA$\mathrm{BAB}$ system will end during collision with and accretion to a 
continental margin, a process that may play a significant role in the growth and evolution of continental crust.

In an intra-OIA-BAB system, there are two sites of magmatic activity: (1) island-arc magmatism along the axis of the magmatic arc and (2) magmatism at the spreading center of the $\mathrm{BAB}$. The $\mathrm{BAB}$ rifting will start in a region near to the axis of the magmatic arc and gradually move away from the subduction zone and the axis with the development of $\mathrm{BAB}$ spreading [31].

Under such tectonic scenarios, geochemical features of back-arc basin basalts (BABBs) will vary with the development of $B A B$ spreading [31-33]. At the initial stage of $B A B$ formation, $B A B B$ s possess geochemical signatures of island-arc basalt (IAB), whereas, at the late stage of BAB formation, the $\mathrm{BABBs}$ possess geochemical signatures of mid-ocean ridge basalt (MORB). Thus, geochemical signatures of BABBs will vary from $I A B$ to $M O R B$ with the development of a $B A B$, with the signatures being controlled by the interaction between the mantle components and the subduction zone components. Consequently, BABBs with $\mathrm{IAB}$ signatures should be older than those with MORB signatures.

4.2. Geochemical Implications for the Evolution of $B A B B$. The variation diagram of the $(\mathrm{Nb} / \mathrm{La})_{N}$ ratio with respect to the $(\mathrm{La} / \mathrm{Y})_{N}$ ratio (Figure 5) characterizes the geochemical signatures in the range between MORB and IAB [7]. Data source for the MORBs are excerpted after Pearce and Parkinson [34], and Kelemen et al. [35]. Those for the Cenozoic BABB and IAB are after Taylor and Martinez [31], and Tatsumi [36], respectively. The MORBs are plotted predominantly in the field of the $(\mathrm{Nb} / \mathrm{La})_{N}$ ratio $>1.0$, while the compositions of IAB [34-36] are plotted in the field of the $(\mathrm{Nb} / \mathrm{La})_{N}$ ratio $<1.0$. In the diagram, compositions of the Cenozoic $\mathrm{BABB}$ are generally plotted in the field between MORB and $I A B$ and broadly include MORB and IAB compositions. Thus, the geochemical signatures of $\mathrm{BABBs}$ are characterized by the compositional trend connecting the fields between MORB and IAB.

Using this diagram, we evaluate the geochemical signatures of metabasalts and metagabbro in the Yakuno ophiolite. Data sources for the mafic rocks in Yakuno ophiolite are excerpted from Suda and Hayasaka [7] and Ichiyama and Ishiwatari [11]. The metagabbros in Yakuno ophiolite plotted in this diagram were evaluated to be the melt origin which do not possess the cumulite compositions by Suda and Hayasaka [7].

The results indicate that the mafic rocks in the Yakuno ophiolite have a clear BAB affinity. In particular, the metagabbros in the Asago area are plotted predominantly in the field around IAB, whereas the metabasalts in the Yakuno-cho area are plotted in the field between IAB and MORB. This may imply that the metagabbro in the Asago area formed during the initiation of $\mathrm{BAB}$ rifting near the axis of the magmatic arc. In contrast, the metabasalts in the Yakuno-cho area have an influence throughout the development of $\mathrm{BAB}$ crust.

4.3. Geotectonic Timescale Model for the Yakuno Intra-OIA$B A B$ System. Geochronological data for the Yakuno ophiolite

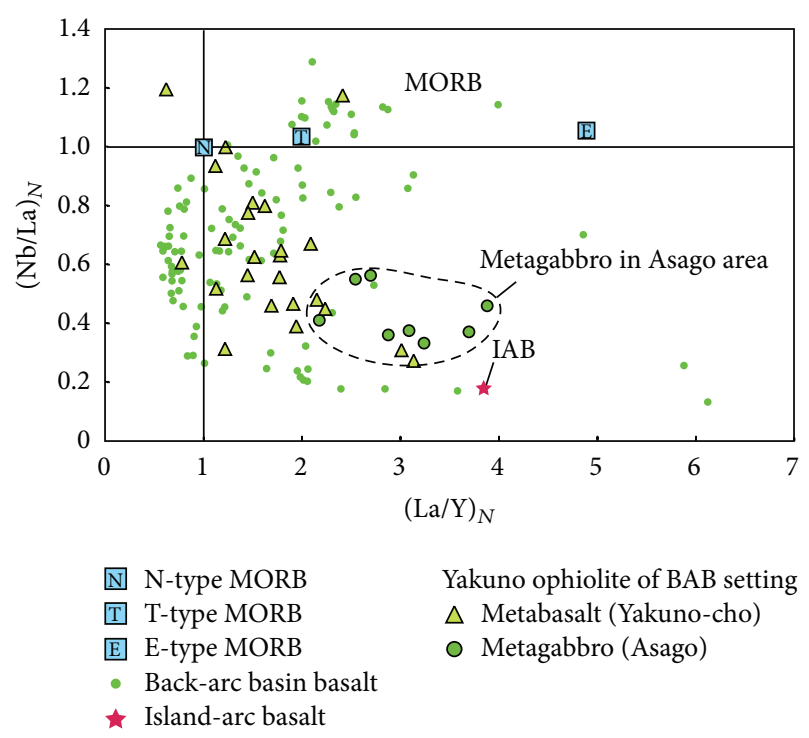

FIGURE 5: Variation diagram of N-MORB normalized La/Nb ratio versus $\mathrm{La} / \mathrm{Y}$ ratio for the metabasalt in the Yakuno-cho area [11] and the noncumulitic metagabbro in the Asago area [7]. Also plotted for comparative purposes are the compositions of Cenozoic back-arc basin basalts (BABBs) in various areas [31], MORBs (N-MORB [34]; T- and E-MORBs [35]), and island-arc basalt (IAB) [36].

and associated rocks after previous studies and the current investigation are compiled in Figure 6. Based on these data, we suggest that the metagabbro and amphibolite in the Asago area formed through igneous activity under the spreading center of BAB rifting at ca. $288-293 \mathrm{Ma}$ (after the present study). The $\mathrm{BAB}$ rocks were intruded by the arc granitoid with a magmatic age of ca. 285-282 Ma (after U-Pb zircon TIMS ages [31]). These results suggest that the BAB crust was brought to the magmatic arc setting soon (within several million years) after its generation.

Koide et al. [37] reported an $\mathrm{Rb}-\mathrm{Sr}$ whole-rock-mineral isochron age of $281 \pm 8 \mathrm{Ma}$ for the metagabbro and metabasalt of $\mathrm{BABB}$ origin in the Ibara area. This age is similar to the age of radiolarians from the lower strata of the Maizuru Group and may represent the magmatic age of the mafic rocks of $\mathrm{BABB}$ origin without the influence of arc magmatism.

Sano [38] reported Sm-Nd whole rock and mineral isochron ages of $409 \pm 44 \mathrm{Ma}$ and $412 \pm 62 \mathrm{Ma}$, respectively, for the metagabbro of MORB origin in the Ayabe area (Figure 1). Hayasaka et al. [6] reported Sm-Nd whole rock and mineral isochron ages of $341 \pm 62 \mathrm{Ma}, 343 \pm 34 \mathrm{Ma}$, and $385 \pm 13 \mathrm{Ma}$ for the metagabbro of MORB origin in the Oshima peninsula and the Asago area (Figure 1). These ages are clearly older than the ages of the magmatic events that produced the granitoid of intra-OIA setting (ca. 285-282 Ma) and BAB crust (ca. 288-293 Ma). Field observations further indicate that these rocks do not show any influence of arc magmatism. Taken together, these results suggest that these older metagabbros of MORB origin might have formed the basement of a forearc basin in the intra-OIA-BAB system.

Many K-Ar hornblende ages and K-Ar biotite ages of metagabbro and metabasalt have been reported for 


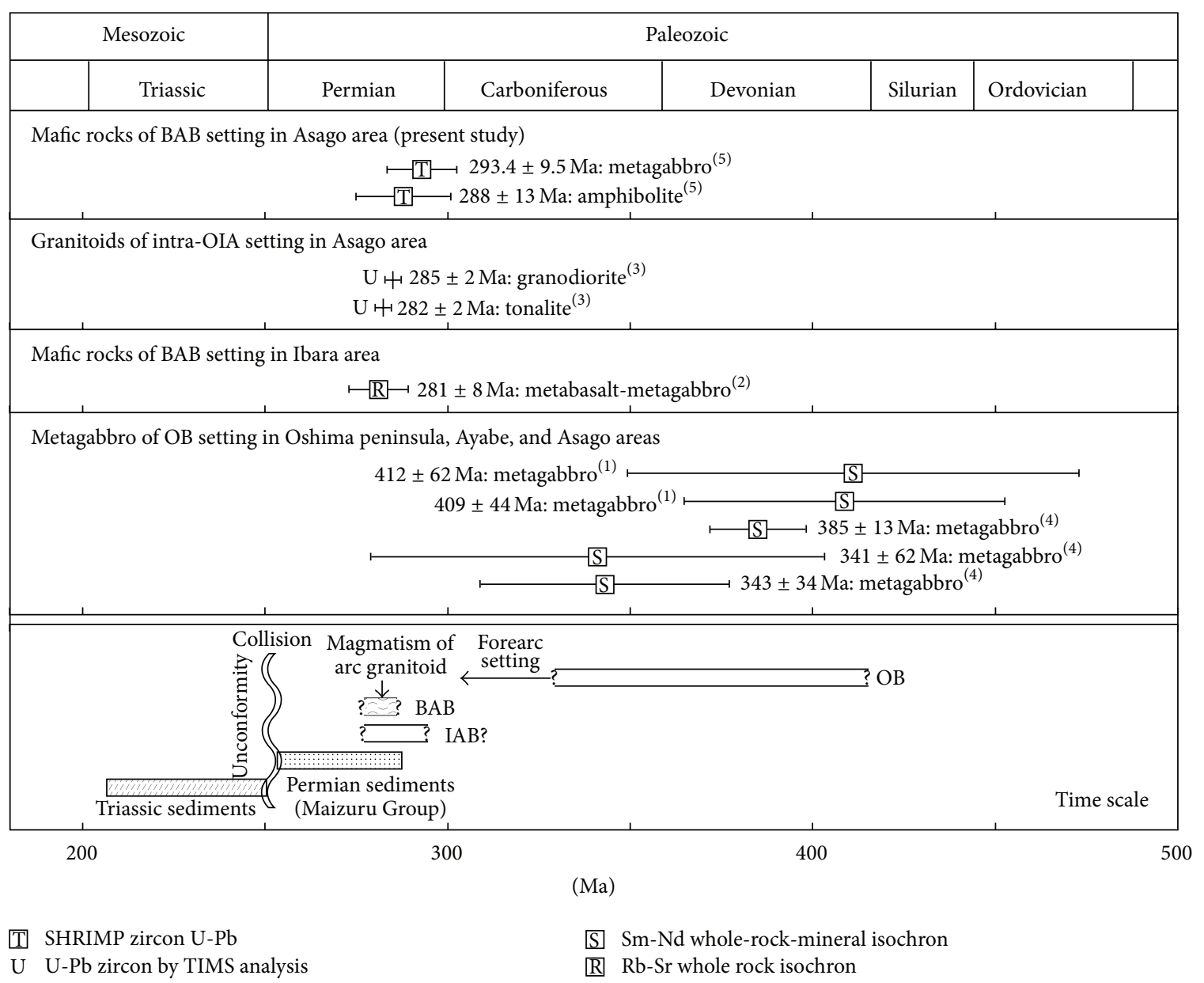

Figure 6: Summary of isotopic ages for the Yakuno ophiolite and stratigraphic ages for the Permo-Triassic sediments in the Maizuru Terrane. Data sources for isotopic ages are (1) Sano [38]; (2) Koide et al. [14]; (3) Herzig et al. [9]; (4) Hayasaka et al. [6]; and (5) the present study.

the Yakuno ophiolite in various areas [39-41]. These ages are concentrated over the interval extending from the middle Permian to the late Triassic, a time frame that may represent the cooling history after the magmatic event in the intra-OIA and $\mathrm{BAB}$ settings.

Based on the above discussion regarding the geology and geochronology of the Maizuru Terrane, we tentatively propose the following model of the geotectonic evolution and time scale for the Yakuno intra-OIA-BAB system.

(1) Initiation of $\mathrm{BABB}$ magmatism under the spreading center of the $\mathrm{BAB}$ rifting formed the $\mathrm{BAB}$ crust with IAB signatures (ca. 293-288 Ma; Figure 7(a)).

(2) The BAB crust gradually moved to the region near the axis of the magmatic arc because of BAB spreading and tectonic erosion of the forearc basin. Subsequently, the BAB crust was overlapped by the axis of the magmatic arc and formed the basement of the OIA (ca. 288-285 Ma; Figure 7(b)).
(3) The IAB magmatism led to the lower crustal anatexis of the OIA basement, consequently generating granitoids of arc affinities (ca. 285-282 Ma). Simultaneously, BABB magmatism under the spreading center of the $\mathrm{BAB}$ rifting formed the $\mathrm{BAB}$ crust with $\mathrm{IAB}$ to MORB signatures, on which terrigenous sediments derived from a nearby continent were deposited, forming the Permian Maizuru Group (<ca. $285 \mathrm{Ma}$; Figure 7(c)).

(4) These Paleozoic components collided and became accreted to the eastern margin of the East Asian continent during the early Mesozoic.

The problems still remaining comprise the evidence of the subduction zone adjacent to the craton (Figure $7(\mathrm{c})$ ) and of how to survive the metagabbro of MORB origin from the Silurian period through the Permian period. The Sm$\mathrm{Nd}$ ages reported from studies on other ophiolites (e.g., in the Variscan Belt of Europe; Kryza and Pin [4]) appeared to be different from SIMS U-Pb zircon age data because of the parent-daughter disturbance and resetting due to the metasomatism and metamorphism. This suggests that 


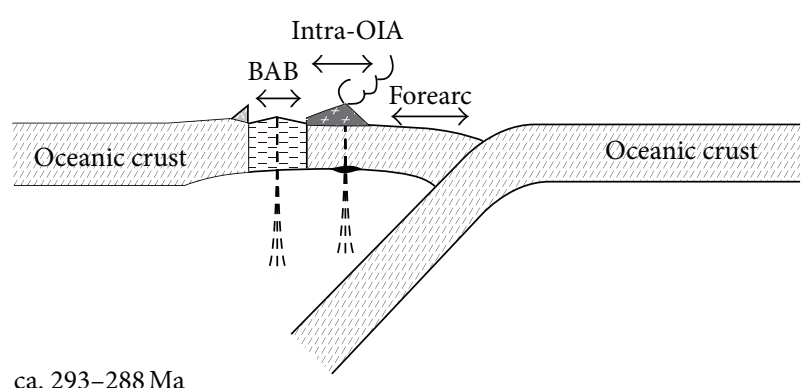

(a)

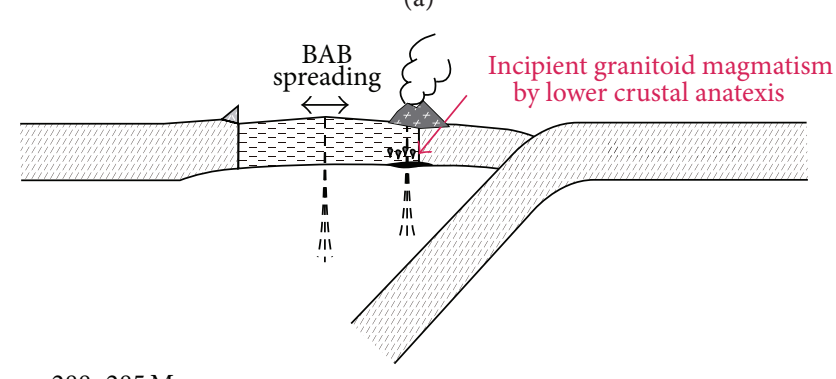

ca. $288-285 \mathrm{Ma}$

(b)

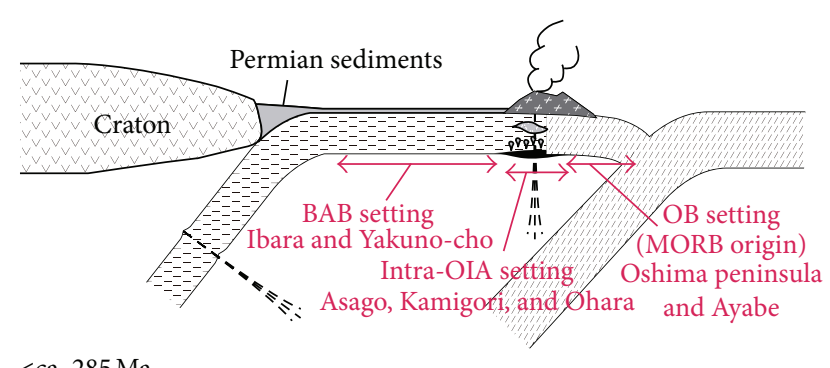

(c)

Figure 7: Tentative geotectonic model and time scale for the Paleozoic intra-OIA-BAB system of the Yakuno ophiolite and associated rocks.

the geochronological significance of the Sm-Nd isotopic ages can be problematic. More precise geochronological investigation on the Yakuno ophiolite of MORB origin in the Oshima peninsula and Ayabe area would be necessary.

\section{Conflict of Interests}

The authors declare that they have no conflict of interests.

\section{Acknowledgments}

The authors express their sincere thanks to Dr. T. Okudaira and Professor Dr. M. Satish-Kumar for their valuable comments and guidance. Earlier version of the paper was improved by Professor Dr. S. Arai and Professor Dr. Harald Furnes. Special thanks go to Professor Dr. R. Kryza for editing this paper. Funding was provided by a Grant-in-Aid for Scientific Research at the Center for Chronological Research at Nagoya University.

\section{References}

[1] Y. Dilek and P. T. Robinson, "Ophiolites in earth history: introduction," in Ophiolites in Earth History, Y. Dilek and P. T. Robinson, Eds., vol. 218 of Geological Society of London Special Publication, pp. 1-8, 2003.

[2] R. G. Coleman, Ophiolites: Ancient Oceanic Lithosphere? Springer, Berlin, Germany, 1977.

[3] Y. Dilek and H. Furnes, "Ophiolite genesis and global tectonics: geochemical and tectonic fingerprinting of ancient oceanic lithosphere," Bulletin of the Geological Society of America, vol. 123, no. 3-4, pp. 387-411, 2011.

[4] R. Kryza and C. Pin, "The Central-Sudetic ophiolites (SW Poland): petrogenetic issues, geochronology and palaeotectonic implications," Gondwana Research, vol. 17, no. 2-3, pp. 292-305, 2010.

[5] A. Ishiwatari, Y. Ikeda, and Y. Koide, "The Yakuno ophiolite, Japan: fragments of Permian island arc and marginal basin crust with the hotspot," in Ophiolites Oceanic Crustal Analogues: Proceedings of the Symposium “Troodos 1987”, J. P. Malpas, E. M. Moores, A. Panayiotou, and C. Xenophontos, Eds., pp. 476-506, Geological Survey Department, Nicosia, Cyprus, 1987.

[6] Y. Hayasaka, K. Ikeda, T. Shishido, and M. Ishizuka, "Geological reconstruction of the Maizuru Terrane as an arc-back arc system," in Tectonics and Metamorphism (The Hara Volume), T. Shimamoto, Y. Hayasaka, T. Shiota et al., Eds., pp. 134-144, Soubun, Tokyo, Japan, 1996, (Japanese with English Abstract).

[7] Y. Suda and Y. Hayasaka, "Genesis and evolutional processes of the Paleozoic oceanic island arc crust, Asago body of the Yakuno ophiolite, southwest Japan," Journal of the Geological Society of Japan, vol. 115, no. 6, pp. 266-287, 2009 (Japanese).

[8] Y. Suda, "Crustal anatexis and evolution of granitoid magma in Permian intra-oceanic island arc, the Asago body of the Yakuno ophiolite, southwest Japan," Journal of Mineralogical and Petrological Sciences, vol. 99, no. 5, pp. 339-356, 2004.

[9] C. T. Herzig, D. L. Kimbrough, and Y. Hayasaka, "Early Permian zircon uranium-lead ages for plagiogranites in the Yakuno ophiolite, Asago district, southwest Japan," Island Arc, vol. 6, pp. 396-403, 1997.

[10] A. Ishiwatari, "Granulite-facies metacumulates of the yakuno ophiolite, Japan: evidence for unusually thick oceanic crust," Journal of Petrology, vol. 26, no. 1, pp. 1-30, 1985.

[11] Y. Ichiyama and A. Ishiwatari, "Petrochemical evidence for off-ridge magmatism in a back-arc setting from the Yakuno ophiolite, Japan," Island Arc, vol. 13, no. 1, pp. 157-177, 2004.

[12] Y. Hayasaka, "Maizuru terrane," in Pre-Cretaceous Terranes of Japan, K. Ichikawa, S. Mizutani, I. Hara, S. Hada, and A. Yao, Eds., pp. 81-95, Nihon-Insatsu, Osaka, Japan, 1990.

[13] A. Ishiwatari, "Fragment of Paleozoic oceanic island arc crust in the Inner Zone of southwest Japan: the Kamigori metagabbro body, Hyogo prefecture," in Ophiolite and Tectonics of Accretionary Complex, S. Miyashita, S. Arai, K. Kiminami, and A. Matsuoka, Eds., vol. 52 of Memoirs of the Geological Society of Japan, pp. 273-285, 1999, (Japanese with English Abstract).

[14] Y. Koide, "Origin of the Ibara metabasalts from the Maizuru tectonic belt, southwest Japan," Journal of Geological Society of Japan, vol. 92, no. 5, pp. 329-348, 1986.

[15] S. Suzuki, "Sedimentary and tectonic history of the eastern part of Maizuru zone, southwest Japan," Geological Report of the Hiroshima University, no. 27, pp. 1-54, 1986 (Japanese).

[16] M. Umeda, S. Takemura, and S. Suzuki, "Permian radiolarians from the lower and middle formation of the Maizuru group 
in the Oe area, northern part of Kyoto prefecture, southwest Japan," in Proceedings of the 5th Radiolarian Symposium, NOM Special Volume no. 10, pp. 41-46, 1997, (Japanese with English Abstract).

[17] H. Ishiga, "Follicucullus (permian radiolaria) from the Maizuru group in the Maizuru belt, southwest Japan," Earth Science, vol. 38, pp. 427-434, 1984.

[18] K. Nakazawa, "The Triassic system in the Maizuru zone, southwest Japan," Memoirs of the College of Science, University of Kyoto B, vol. 24, pp. 285-313, 1958.

[19] H. Kano, K. Nakazawa, Y. Igi, and T. Shiki, "On the biotite origin vermiculite from the Shidaka unconformity and its geologic significance," Journal of Geological Society of Japan, vol. 68, no. 797, pp. 65-74, 1962 (Japanese).

[20] F. Kobayashi, "Palaeogeographic constraints on the tectonic evolution of the Maizuru Terrane of southwest Japan to the eastern continental margin of south China during the Permian and Triassic," Palaeogeography, Palaeoclimatology, Palaeoecology, vol. 195, no. 3-4, pp. 299-317, 2003.

[21] J. Tazawa, "Late Permian Boreal-Tethyan mixed brachiopod faunas from the Maizuru Group, southwest Japan, and their paleobiogeographic and tectonic significance," Journal of Geological Society of Japan, vol. 112, no. 8, pp. 510-518, 2006 (Japanese).

[22] M. Fujii, Y. Hayasaka, and K. Terada, "SHRIMP zircon and EPMA monazite dating of granitic rocks from the Maizuru terrane, southwest Japan: correlation with east Asian Paleozoic terranes and geological implications," Island Arc, vol. 17, no. 3, pp. 322-341, 2008.

[23] K. R. Ludwig, "User's manual for isoplot 3.00," Berkeley Geochronology Center Special Publication, no. 4, pp. 1-71, 2003.

[24] F. Tera and G. J. Wasserburg, "U-Th-Pb systematics in three Apollo 14 basalts and the problem of initial $\mathrm{Pb}$ in lunar rocks," Earth and Planetary Science Letters, vol. 14, no. 3, pp. 281-304, 1972.

[25] D. Rubatto, "Zircon trace element geochemistry: partitioning with garnet and the link between $\mathrm{U}-\mathrm{Pb}$ ages and metamorphism," Chemical Geology, vol. 184, no. 1-2, pp. 123-138, 2002.

[26] P. T. Leat and R. D. Larter, "Intra-oceanic subduction systems: an introduction," in Intra-Oceanic Subduction Systems: Tectonic and Magmatic Processes, R. D. Larter and P. T. Leat, Eds., vol. 219 of Geological Society of London Special Publication, pp. 1-17, 2003.

[27] S. P. Johnson and G. J. H. Oliver, "Mesoproterozoic oceanic subduction, island-arc formation and the initiation of backarc spreading in the Kibaran belt of central, southern Africa: evidence from the Ophiolite Terrane, Chewore Inliers, northern Zimbabwe," Precambrian Research, vol. 103, no. 3-4, pp. 125-146, 2000.

[28] Y. Suda, Y. Kawano, G. Yaxley, H. Korenaga, and Y. Hiroi, "Magmatic evolution and tectonic setting of metabasites from Lützow-Holm Complex, East Antarctica," in Geodynamic Evolution of East Antarctica: A Key to the East-West Gondwana Connection, M. Satish-Kumar, Y. Motoyoshi, Y. Osanai, Y. Hiroi, and K. Shiraishi, Eds., vol. 308 of Geological Society of London Special Publication, pp. 211-233, 2008.

[29] E. Honza and K. Fujioka, "Formation of arcs and backarc basins inferred from the tectonic evolution of southeast Asia since the late cretaceous," Tectonophysics, vol. 384, no. 1-4, pp. 23-53, 2004.

[30] K. Tani, D. J. Dunkley, J.-I. Kimura, R. J. Wysoczanski, K. Yamada, and Y. Tatsumi, "Syncollisional rapid granitic magma formation in an arc-arc collision zone: evidence from the tanzawa plutonic complex, Japan," Geology, vol. 38, no. 3, pp. 215-218, 2010.

[31] B. Taylor and F. Martinez, "Back-arc basin basalt systematics," Earth and Planetary Science Letters, vol. 210, no. 3-4, pp. 481497, 2003.

[32] A. D. Saunders and J. Tarney, "Geochemical characteristics of basaltic volcanism within back-arc basin," in Marginal Basin Geology, B. P. Kokelaar and M. F. Howells, Eds., vol. 16 of Geological Society of London Special Publication, pp. 46-76, 1984.

[33] J. A. Pearce and R. J. Stern, "The origin of back-arc basin magmas: trace element and isotope perspectives," Geophysical Monograph, vol. 166, pp. 63-86, 2006.

[34] J. A. Pearce and I. J. Parkinson, "Trace element models for mantle melting: application to volcanic arc petrogenesis," in Magmatic Processes and Plate Tectonics, H. M. Prichard, T. Alabaster, N. B. W. Harris, and C. R. Neary, Eds., vol. 76 of Geological Society of London Special Publication, pp. 373-403, 1993.

[35] P. B. Kelemen, K. Hanghoj, and A. R. Greene, "One view of the geochemistry of subduction-related magmatic arcs, with an emphasis on primitive andesite and lower crust," in Treatise of Geochemistry, R. L. Rudnick and K. K. Turekian, Eds., vol. 3, pp. 593-659, 2003.

[36] Y. Tatsumi, "Continental crust formation by crustal delamination in subduction zones and complementary accumulation of the enriched mantle I component in the mantle," Geochemistry, Geophysics, Geosystems, vol. 1, no. 12, 2000.

[37] T. Koide, K. Tazaki, and H. Kagami, "Sr isotopic study of Ibara dismembered ophiolite from the Maizuru Tectonic belt, southwest Japan," Journal of Mineralogy, Petrology and Economic Geology, vol. 82, no. 1, pp. 1-15, 1987.

[38] S. Sano, "Neodymium isotopic compositions of Silurian Yakuno metagabbros," Journal of Mineralogy, Petrology and Economic Geology, vol. 87, no. 7, pp. 272-282, 1992 (Japanese).

[39] K. Shibata and S. Igi, "K-Ar ages of the Maizuru Metamorphic rocks (Komori M. R.)," Journal of Geological Society of Japan, vol. 72, no. 7, pp. 358-360, 1966 (Japanese).

[40] K. Shibata, S. Igi, and S. Uchiumi, "K-Ar ages of hornblendes from gabbroic rocks in southwest Japan," Geochemical Journal, vol. 11, no. 2, pp. 57-64, 1977.

[41] K. Shibata, S. Uchiumi, and F. Nakazawa, "K-Ar age results-1," Bulletin of Geological Survey of Japan, no. 30, pp. 675-686, 1979 (Japanese). 

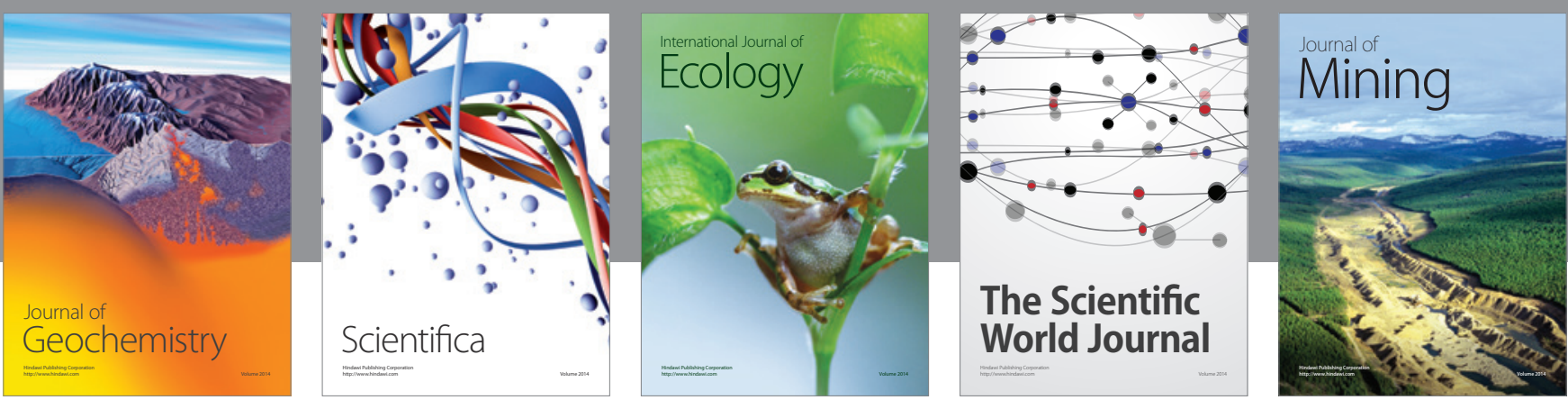

The Scientific World Journal
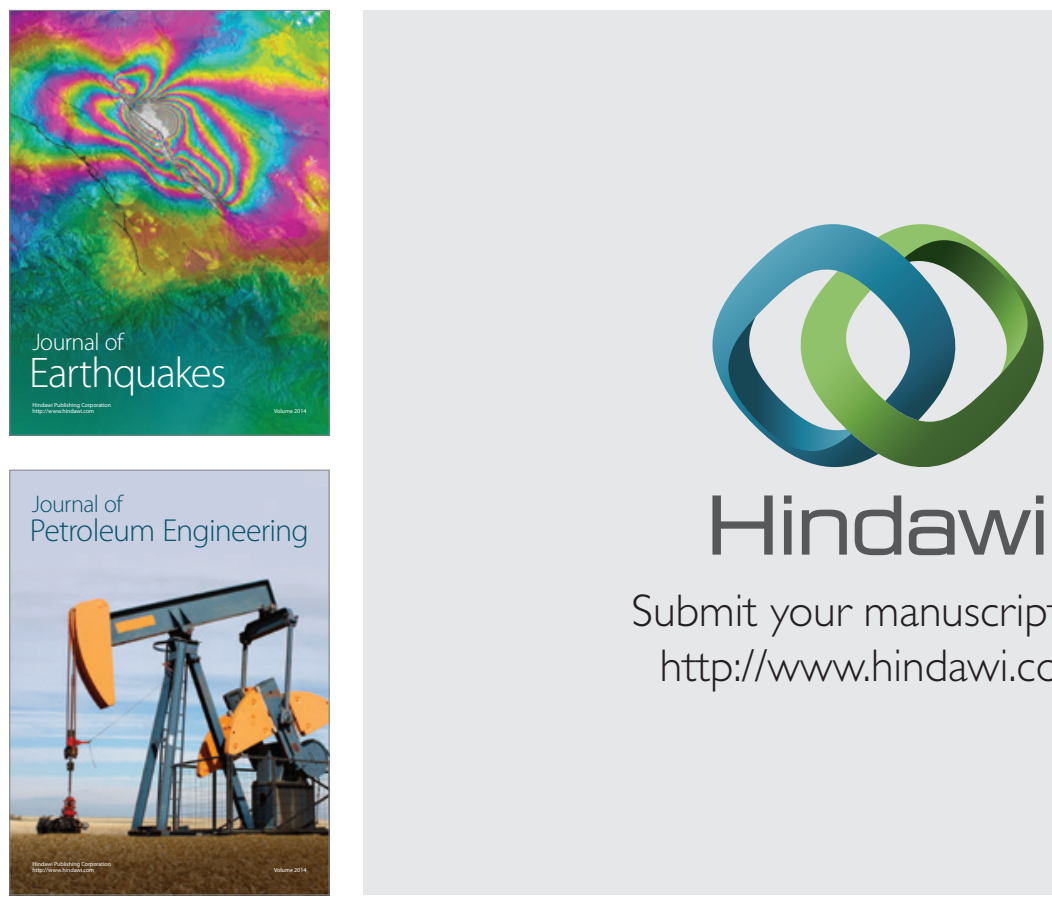

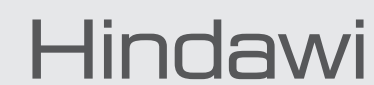

Submit your manuscripts at

http://www.hindawi.com
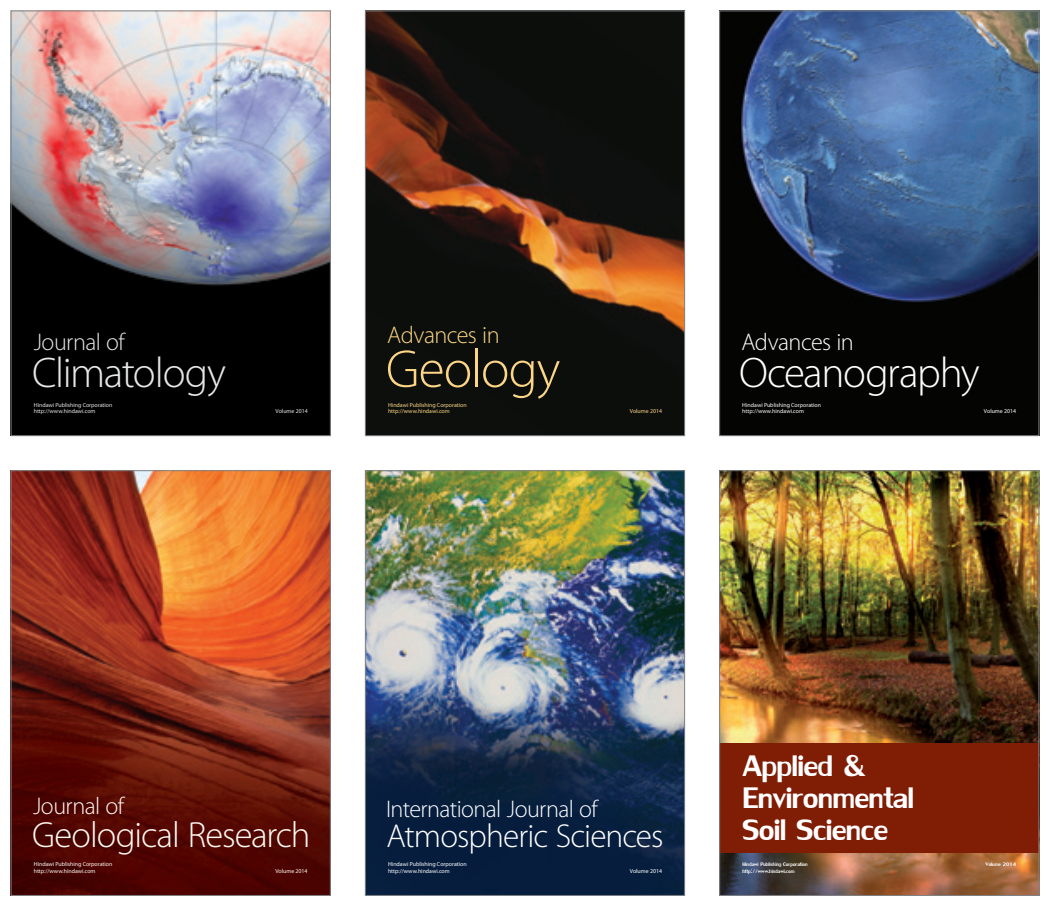
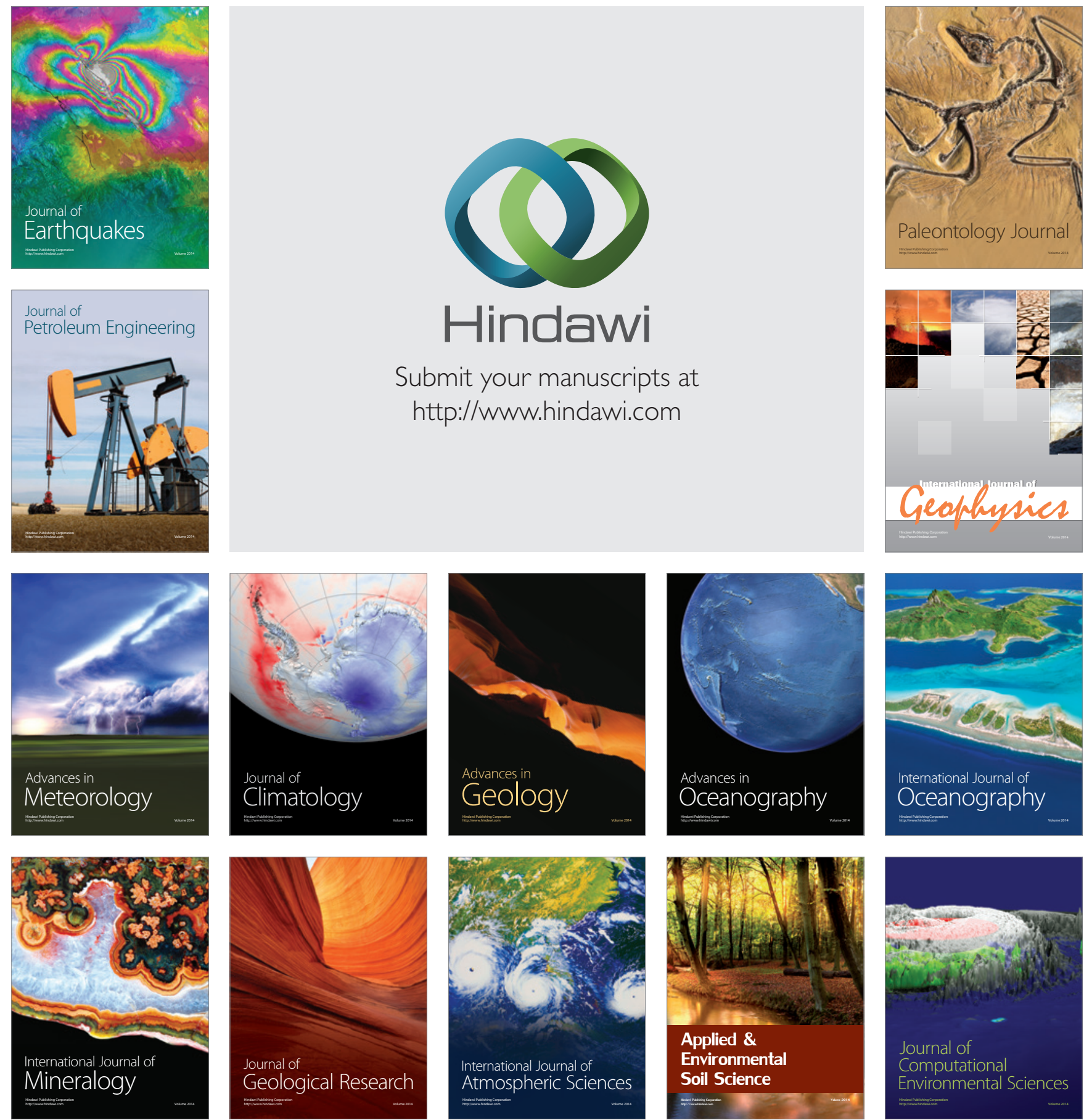